Artikel Riset

DOI : $10.33751 /$ jf.v8i1.11768
Fitofarmaka Jurnal Ilmiah Farmasi

Vol. 8, No.1, Juni 2018 : 25-31

p-ISSN : 2087-9164 e-ISSN : 2622-755X

\title{
RED GINGER (Zingiber officinale var. rubrum): ITS CHEMICAL CONSTITUENTS, PHARMACOLOGICAL ACTIVITIES AND SAFETY
}

\author{
Rini Daud Supu ${ }^{1,2^{*}}$, Ajeng Diantini ${ }^{1}$, Jutti Levita ${ }^{1}$ \\ ${ }^{1}$ Department of Pharmacology and Clinical Pharmacy, Universitas Padjadjaran, \\ Bandung 45363, West Java, Indonesia \\ ${ }^{2}$ Faculty of Pharmacy, Universitas Indonesia Timur, Makassar 90222, \\ East Java, Indonesia \\ *E-mail: rinidaudsupu90@gmail.com
}

\begin{abstract}
Ginger (Zingiber officinale) which belongs to the Zingiberaceae family, was first cultivated in Asia (Indonesia and Malaysia). This plant is one of the most commonly used herbal supplements taken by many patients to treat various conditions. Z.officinale has three varieties based on its size, colors of rhizome and chemical constituents i.e. Z. officinale var. officinale (big white ginger or giant ginger, badak or gajah), Z. officinale var. amarum (small white ginger, emprit), and Z. officinale var. rubrum (small red ginger, merah or beureum). These three varieties may partly be deferred from their essential oil contents and are used for different purposes. The essential oils contained in Z. officinale var. rubrum are higher than the other types of ginger, which makes stronger in its pungency smell and taste. There are many studies that confirm beneficial effects of red ginger against the symptoms of diseases, i.e. antiinflammation, antioxidant, antiemetic, antibacterial and antidiabetics. Z.officinale var. rubrum is considered to be a safe herbal medicine with only few and insignificant adverse/side effects. Although the medicinal properties of red ginger have been known, further trials in humans are required to determine the efficacy of red ginger (or one or more of its constituents) and to establish what, if any, adverse effects are observed.
\end{abstract}

Key words: Zingiber officinale, ginger, herbal supplement

\begin{abstract}
ABSTRAK
Tanaman jahe (Zingiber officinale) termasuk kedalam famili Zingeberaceae, pertama kali dikultivasi di Asia (Indonesia dan Malaysia). Tanaman ini umumnya digunakan sebagai suplemen herbal oleh masyarakat untuk meredakan berbagai keluhan penyakit. $Z$ officinale terdiri dari 3 varietas berdasarkan ukuran rimpang, warna rimpang dan kandungan bahan kimianya yaitu $Z$ officinale var. officinale (jahe putih besar, jahe badak, atau jahe gajah), Z. officinale var. amarum (jahe putih kecil atau jahe emprit), dan Z. officinale var. rubrum (jahe merah kecil, atau jahe beureum). Ketiga varietas ini sebagian berbeda dalam kandungan minyak esensialnya dan digunakan untuk keperluan yang berbeda. Minyak esensial yang terkandung dalam $Z$. officinale var. rubrum lebih tinggi dari jahe tipe lainnya sehingga jahe ini memiliki bau dan rasa yang lebih pedas.
\end{abstract}


Berbagai studi telah membuktikan bahwa jahe merah memiliki aktifitas positif terhadap berbagai gejala penyakit seperti antiinflamasi, antioksidan, antiemetik, antibacterial, dan antidabetik. Z.officinale var. rubrum diperkirakan dapat dimanfaatkan sebagai obat herbal yang aman tanpa efek samping, atau efek samping minimal. Walaupun manfaat medis jahe merah telah diketahui secara saintifik, namun diperlukan uji klinis lebih lanjut untuk mengetahui tingkat kemanjuran serta kandungan senyawa secara lebih spesifik, serta mempelajari efek-efek samping yang mungkin terjadi.

Kata kunci: Zingiber officinale, jahe, suplemen herbal

\section{INTRODUCTION}

Herbal medicines are currently in great demand in developed countries for primary health care because of its usefulness, safety and lower side effects (Bhargava et al., 2012). According to a report by the World Health Organization, $80 \%$ of the population in developing countries depend on herbal medicine for their primary health care, and $85 \%$ of herbal medicine are derived from plants (Ghasemzadeh et al., 2015).

The rhizome of Zingiber officinale has been used as a component in Indonesian jamu. This particular plant is classified into three varieties based on its size, colors of rhizome, and chemical constituents, i.e. Z. officinale var. officinale Roscoe (big white ginger or giant ginger, badak or gajah), $\mathrm{Z}$. officinale var. amarum (small white ginger, emprit), and $Z$. officinale var. rubrum (small red ginger, merah or beureum) (Figure 1). The essential oils of the big white ginger is the lowest compared to the other varieties. The big white ginger is commonly used for food and beverages, while the others are mostly used for medicinal purposes (Setyawan et al., 2014).

Z. officinale var. rubrum (Zingiberaceae) was first cultivated in Asia (Indonesia and Malaysia) but is now cultivated in the West and other tropical regions (Africa, India). Rhizome of red ginger has been used as seasoning ingredient, food flavor, as well as herbal medicine (Singletary, 2010; Bhattarai et al., 2001). There are many studies that confirmed benefical effects of red ginger as anti-inflammatory, antiemetic, antitumor, analgesic, anti-hemorrhagic, neuronal cell protective, anti-rheumatic, antifungal, and antibacterial agent (Mesomo et al., 2012; Kumar et al., 2011).

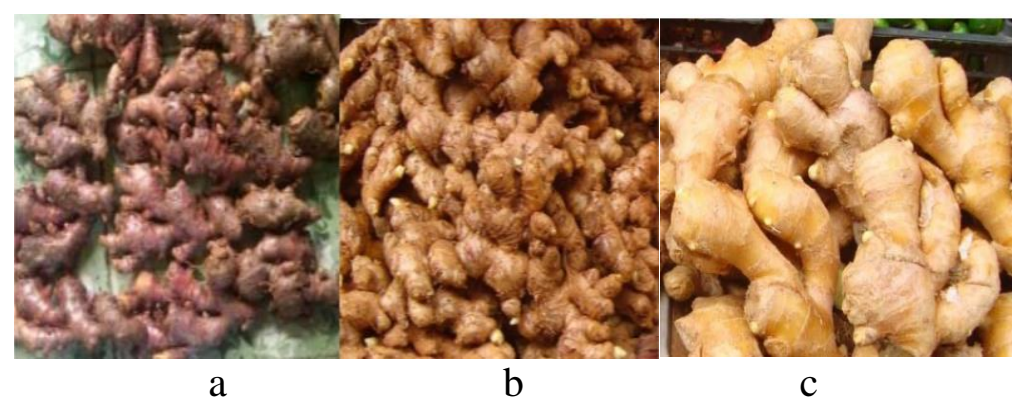

Figure 1. Rhizome of Z. officinale var. rubrum (a), Z. officinale var. amarum (b), Z. officinale var. officinale Roscoe (c) 
Table 1. Taxonomy of Z. Officinale var. Rubrum

\begin{tabular}{ll}
\hline Kingdom & : Plantae \\
\hline Division & : Magnoliophyta \\
Class & : Liliopsida \\
Order & $:$ Zingiberales \\
Family & $:$ Zingiberaceae \\
Genus & $:$ Zingiber \\
Species & $:$ Zingiber officinale \\
Variety & : Zingiber officinale var. rubrum \\
\hline
\end{tabular}

\section{Botanical Description}

$Z$. officinale var. rubrum is an annual plant that can grow up to 50-100 $\mathrm{cm}$ tall. The leaves are lancet-shaped with a length of $5-25 \mathrm{~cm}$ and width of 1.5-2 $\mathrm{cm}$, the tip of the pointed leaves and clasping the stem by long sheaths. Stems grow perpendicular and rounded flat, not branched. Flowers are compounded and ovoid with stem length $10-25 \mathrm{~cm}$ oval shaped with a stalk length of $10-25 \mathrm{~cm}$ and crown of flowers purple measuring 2$2.5 \mathrm{~cm}$. Small flower petals are tubular and jagged three. The fleshy rhizomes are thick and reddish-brown and red rhizome skin. The single root is getting bigger along with its age, to form the rhizomes and shoots that will grow into new plants. The roots grow from the bottom of the rhizome, while the buds will grow from the top of the rhizomes (Ross, 1999 and Supriadi et al., 2011).

\section{Phytochemistry}

The chemical constituents of this plant varies considerably, depending on

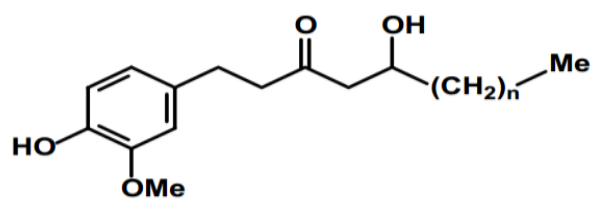

[4]-, [6]-, [8]-, and [10]-gingerol the location of cultivation and whether the product is fresh, dried, or processed (Singletary, 2010). Chemical analysis of $Z$. officinale var. rubrum showed over 400 different compounds. The major constituents in ginger rhizomes are carbohydrates $(50-70 \%)$, lipids $(3-8 \%)$, terpenes (zingiberene, $\beta$-bisabolene, $\alpha$ farnesene, $\beta$-sesquiphellandrene, and $\alpha$ curcumene), and phenolic compounds (gingerol, paradols, and shogaol) The characteristic odor and flavor of ginger are due to a mixture of volatile oils like shogaols and gingerols. Gingerols and shogaol were found in higher amounts in the other two types of ginger with average levels of gingerol $(23-25 \%)$ and shogaol (18-25\%) (Prasad S. dan Tyagi, K. A. (2015).

Gingerol were identified among other [4, [6]-, [8]-, and [10]-gingerol, while shogaol were identified [4]-, [6]-, [8]-, [10]- and [12]-shogaol (Figure 2) (Ali et al., 2008).

Figure 2. Chemical structures of gingerol and shogao

The pungency of fresh ginger is due primarily to the gingerol, of which [6]-gingerol is most abundant. While on the other hand, dry ginger exhibits a 
pungency due to the shogaol [6]-shogaol. Shogaols are formed from the corresponding gingerol during thermal processing (Wohlmuth, 2005). Degradation rates of gingerol to shogaol were also found to be $\mathrm{pH}$ dependent, with greatest stability at $\mathrm{pH} 4$, whereas at $100^{\circ}$ $\mathrm{C}$ and $\mathrm{pH} \mathrm{1,} \mathrm{the} \mathrm{reversible} \mathrm{degradation}$ was relatively rapid (Bhattarai et al., 2001).

\section{Pharmacological Activities}

The rhizome of $Z$. officinale, var. rubrum was reported for various medicinal properties including antiinflammatory activity, anti-oxidant activity, anti-nausea/antiemetic activity, anti-bacterial activity, cytotoxic activity and antidiabetic activity.

\section{Anti-Inflammatory Activity}

The effect of $Z$. officinale, var. rubrum extract $(10-100 \mathrm{mg} / \mathrm{kg})$ on acute inflammation was experimented on acetic acid induced abdominal inflammation model in mice ${ }^{4}$ In addition, intraperitoneal injection of [6]-gingerol $(50 \mathrm{mg} / \mathrm{kg})$ relieved pain by $50 \%$. As revealed in this experiment, this plant extract in low oral dose of $0.2-2 \mathrm{mg} / \mathrm{kg}$ demonstrated effective analgesic and antiinflammatory effects suggesting the synergisms of various physiological compounds presents in the extract (Shan et al., 2010).

\section{Antioxidant Activity}

Ginger extracts inhibited lipid peroxidation by $72 \%$ in human erythrocyte membranes, whereas in human chondrocytes, ginger's volatile oil effectively prevented the production of hydrogen peroxide usually induced by fulvic acid. Animal study using high fat diet rat model revealed that supplementation with ginger provided significant antioxidant effects, raising tissue concentrations of superoxide dismutase and catalase and reducing glutathione (Kemper, 1999). In addition, the antioxidant effect of $Z$. officinale was reported by DPPH radical scavenging activity. The total phenolic content in the alcoholic extract of the dried rhizome of Z. officinale was $870.1 \mathrm{mg} / \mathrm{g}$ of dry extract. The extract exhibited $90.1 \%$ of DPPH radical scavenging activity with the IC50 concentration of $0.64 \mu \mathrm{g} / \mathrm{ml}$ (Kumar et al., 2011).

\section{Antinausea/Antiemetic}

Some of the disparities in study outcomes may be due to differences in dosages used. Typically $1 \mathrm{~g} / \mathrm{d}$ of ginger powder was administered, although in some studies doses as low as $0.3 \mathrm{~g} / \mathrm{d}$ and as high as $2.0 \mathrm{~g} / \mathrm{d}$ were evaluated. Differences in timing of outcome measurements also could have contributed to disparities. In those studies demonstrating efficacy, there were generally no adverse effects (Chaiyakunapruk et al., 2006). Ginger also may act on the 5-HT3 receptor ionchannel complex in the gastrointestinal tract. In humans, ginger intake (1-2 g) may block production of gastric prostaglandins and decrease plasma vasopressin release induced by circular vection (Riyazi et al., 2007).

\section{Antibacterial}

In vitro studies of ginger extracts and ginger chemical constituents have been reported and indicated a growth suppression of various common infectious bacteria including Staphylococcus aureus and Listeria monocytogenes (Norajid et al., 2007). The inhibitory activity of of gingerols and phenolic metabolites towards the growth of Helicobacter pylori suggested a new 
potential use of ginger in combating $H$. pylori related gastrointestinal diseases (Siddaraju dan Dharmesh, 2007).

\section{Cytotoxic Activity}

Red ginger extract revealed anticancer activity through inhibition of $\mathrm{NF}-\kappa \mathrm{B}$ activation, furthermore this plant showed anti-inflammatory activity through inhibition of TNF- $\alpha$. Single-dose toxicity test using $2000 \mathrm{mg} / \mathrm{kg}$ of red ginger extract (maximum dosage without burden on animals) resulted no fatal event and no abnormal changes in the weight of mice (compared to control). Similarly, no abnormal changes detected in organs of mice upon partial inspection conducted after the test. The LD50 (oral) of red ginger extract on male/female mice is deduced to be $>2,000 \mathrm{mg} / \mathrm{kg}$ (Kitagata $e t$ al., 2011).

\section{Antidiabetic Activity}

Hypoglycaemic activity of ginger was reported in streptozotocin-induced diabetic rats. Treatment with aqueous extract $(500 \mathrm{mg} / \mathrm{kg}$ body weight, i.p.) of ginger for a period of 7 weeks significantly decreased the serum glucose, cholesterol and triacylglycerol levels in the diabetic-induced rats compared with the control group (Alamin et al., 2006). Treatment with ginger juice in streptozotocin-induced type I diabetic rats resulted a significant increase in insulin levels and a decrease in fasting glucose levels. Ginger treatment also caused a decrease in serum cholesterol, serum triglyceride and blood pressure in diabetic rats (Akhani et al., 2004).

\section{Safety and Dosage}

The Food and Drug Administration has given ginger GRAS (generally recognized as safe) status for use as a food supplement. Food allergy to spices is infrequent Aside from mild stomach upset in persons unaccustomed to spicy foods, ginger has no known acute toxicity at the usual doses consumed for dietary or medicinal purposes. Very large doses of 6 grams or more of ginger may lead to gastric irritation and loss of protective gastric mucosa. At normal doses (up to 2 grams daily), ginger does not interfere with blood clotting or any individual coagulation parameter. A dose of $0.5-1.0 \mathrm{~g}$ of ginger powder ingested 2-3 times for periods ranging from 3 months to 2.5 years did not cause any adverse effects. The British Herbal Compendium documents no adverse effects of ginger. The acute oral LD 50 in rats of roasted ginger is $170 \mathrm{~g} / \mathrm{kg}$ body weight. Dry ginger is more than $250 \mathrm{~g} / \mathrm{kg}$ body weight. In addition other research, the acute LD50 of ginger in rats is greater than 5 grams of ginger oil per kilogram of body weight (Singletary, 2010; Kumar, 2011).

Red ginger can be consumed as a fresh or dried root and is often prepared in teas, soft drinks (including ales), and breads. No specific dosing studies have been performed; however, most clinical research has used between $250 \mathrm{mg}$ and 1 $\mathrm{g}$ of the powdered root in capsular form, taken one to four times daily. Recommended daily dose for (1) red ginger extract: $15-20 \mathrm{mg}^{4}$, (2) dried powder: $250-1000 \mathrm{mg}$ four times daily by mouth. Chinese herbalists may use up to 10 times this amount (Kemfer, 1999 and White, 2007).

\section{CONCLUSION}

$Z$ officinale var. rubrum is considered to be a safe herbal medicine with only few and insignificant adverse/side effects. Although the medicinal properties of red ginger have 
been known for thousands of years, a significant number of in vitro, in vivo, and epidemiological studies further provide substantial evidence that ginger and its active compounds are effective against wide variety of human diseases. Further trials in humans are required to determine the efficacy of red ginger (or one or more of its constituents) and to establish what, if any, adverse effects are observed.

\section{REFERENCES}

Ali, J. B., G. Blunden, G., M.O. Tanira \& A. Nemmar. 2008. Some Phytochemical, Pharmacological and Toxicological Properties of Ginger (Zingiber officinale Roscoe): A Review of Recent Research. Food Chem. Toxicol. 46(2): 409-420.

Al-amin, Z.M., M. Thomson, K.K. AlQattan, R. Peltonen-Shalaby, M. Ali. (2006). Antidiabetic and hypolipidaemic properties of ginger (Zingiber officinale) in streptozotocin-induced diabetic rats, Br. J. Nut. 96: 660-666.

Akhani S.P., S.L. Vishwakarma \& R.K. Goyal. 2004. Anti-diabetic activity of Zingiber officinale in streptozotocin-induced type I diabetic rats. J. Pharm. Pharmacol.. 56(1): 101-105.

Bhargava, S., D. K. Shipra, A. Batra, A. Sharma, B. Malhotra. 2012. Zingiber officinale: Chemical and phytochemical screening and evaluation of its activities. $J$. Chem. Pharm. Res. 4(1): 360-364.

Bhattarai, S., H.V. Tran, C.C. Duke. (2001). The Satbility of gingerol and shogaol in aqueous solution. Journal of Pharmacetical Sciences. 90:1658-1664
Chaiyakunapruk N., N. Kitikannakorn, S. Nathisuwan, K. Leeprakobboon \& C. Leelasettagool. 2006. The efficacy of ginger for the prevention of postoperative nausea and vomiting: a metaanalysis. Obstet. Gynecol. 194(1): 95-99.

Ghasemzadeh, A., H. Jaafar \& A. Rahmat. 2015. Optimization protocol for the extraction of 6gingerol and 6-shogaol from Zingiber officinale var. Rubrum theilade and improving antioxidant and anticancer activity using response surface methodology. BMC Complement. Altern. Med. 15(258): 1-10.

Kemfer, J.K. 1999. Ginger (Zingiber officinale). The Longwood Herbal and Task Force and The Center for Holistic Pediatric Education and Research.

Kitagata, C. N., I. Ichinomiya \& A. Aichi. 2011. Red ginger extract an all natural anti-arthritic and anti inflammatory agent for food and cosmetics applications. Oryza Oil and Fat Chem. 1-31.

Kumar, G., I. Karthik \& Rao, B. 2011. A Review on pharmacological and phytochemical properties of Zingiber officinale roscoe (Zingiberaceae). J. Pharm. Res. 4: 2963-2966.

Marwat, K.S., M. Shoaib, A.E. Khan, F. Rehman, H. \& Ullah, H. 2015. Phytochemistry and bioactivities of Quranic plant, zanjabil-ginger (Zingiber officinale Roscoe): A review. American-Eurasian $J$. Agric \& Environ. Sci. 15(5): 707713.

Mesomo, C.M., A.P. Scheer, E. Perez, E., P.M. Ndiaye \& L.M. Corazza. 2012. Ginger (Zingiber officinale 
R.) extracts obtained using supercritical $\mathrm{CO} 2$ and compressed propane: kinetics and antioxidant activity evaluation. The Journal of Supercritical Fluids. Brazil. 71: 102-109.

Norajid, K., N. Laohakunjit, O. \& Kerdchoenchuen. 2007. Antibacterial effect of five Zingiberaceae essential oils. Molecules. 12:2047-2060.

Prasad, S. \& K.A.Tyagi. 2015. Ginger and its constituents: role in prevention and treatment of gastrointestinal cancer. Gastroenterology Research and Practice. 1 - 12.

Riyazi A., A. Hensel, K. Bauer, N. Geissler, S. Schaaf \& E. Verspohl. 2007. The effects of the volatile oil from ginger rhizomes (Zingiber officinale), its fractions and isolated compounds on the 5HT3 receptor complex and the seratoninergic system of the rat ileum. Planta Medica. 73:355362.

Ross. I. 1999. Medical Plants of the World Chemical Constituet Traditional and Modern Medical Uses. Human Press. New Jersey.

Setyawan, D.A., W. Wiryanto., S. Suranto \& N. Bermawie. 2014. Short communication: Variation in isozymic pattern of germplasm from three ginger (Zingiber officinale) varieties. Nusantara Biosci. 6(1): 86-93.
Shan, S.J., J. Tanaka, A. Seki, J.W. Seo, N. Kasajima, S. Tamura, Y. Ke \& N. Murakami N. 2010. Antiinflamatory properties of red ginger (Zingiber officinale var. Rubra) extract and suppression of nitric oxide production by its constituents. J. Med. Food. 13(1): 156-162.

Siddaraju, M. \& S. Dharmesh. 2007. Inhibition of gastric $\mathrm{H}+, \mathrm{K}+-$ ATPase and helicobacter pylori by phenolic antioxidants of Zingiber officinale. Mol. Nutr. Food. 51:324-332.

Singletary, K. 2010 : Ginger, An overview of health benefits. Food Sci. 45(4). 171-183.

Supriadi S., Y. Yusron, D. Wahyuno. 2011. Ginger (Zingiber officinale Rosc.). Research Institute for Medicinal and Aromatic Plants. Ministry of Agriculture. 1 - 19.

White, B. 2007. Ginger: an overview. Complementary and Alternative Medicine. American Academy of Family Physicians. University of Southern California, Los Angeles, California..

Wohlmuth, H., D.N. Leach, M.K. Smith, S.P. Myers. 2005. Gingerol content of diploid and tetraploid clones of ginger (Zingiber officinale Roscoe). J. Agric. Food Chem. 53(14): 5772-5778. 